\title{
Percutaneous transluminal septal myocardial ablation (PTSMA) of hypertrophic cardiomyopathy: Indonesian initial experience
}

\author{
Yoga Yuniadi, ${ }^{1}$ Ario S. Koencoro, ${ }^{1}$ Dicky A. Hanafy, ${ }^{1}$ Doni Firman, ${ }^{l}$ Amiliana M. Soesanto, ${ }^{1}$ Hubert Seggewiss ${ }^{2}$ \\ ${ }^{1}$ Department of Cardiology and Vascular Medicine, Faculty of Medicine, University of Indonesia, and National Cardiovascular \\ Center Harapan Kita, Jakarta, Indonesia \\ ${ }^{2}$ Leopoldina Hospital, Schweinfurt, Germany
}

\begin{abstract}
Abstrak
Tujuan Percutaneous transluminal septal myocardial ablation (PTSMA), adalah suatu intervensi non-bedah untuk terapi kardiomiopati hipertropi (KMH), telah menjadi terapi standar di negara-negara maju. Di Indonesia PTSMA belum secara sistematis dilakukan. Seri kasus ini bertujuan untuk mengetahui fisibiliti, efektifitas dan keamanan PTSMA di Pusat Jantung Nasional Harapan Kita.
\end{abstract}

Metoda Tiga pasien KMH (2 laki-laki) dengan gradient tekanan dinamik jalan keluar ventrikel kiri (JKVKi) lebih dari 30 mmHg dilakukan PTSMA. Tekanan apeks ventrikel kiri diukur memakai kateter multipurpose sedangkan tekanan aorta diukur dengan kateter penuntun secara simultan. Pembuluh darah target dikonfirmasi dengan kontras ekokardiografi miokardium. Dua cc alcohol absolute disuntikkan ke pembuluh target melalui balon over the wire. Perubahan gradient tekanan JKVKi diukur kembali 10 menit pasca pemberian alcohol. EKG dimonitor secara terus menerus sepanjang prosedur.

Hasil Seluruh subyek mengalami penurunan gradient tekanan JKVKi lebih dari 50\%. Satu pasien mengalami total AV blok dan blok berkas cabang kanan sementara yang pulih kembali 6 jam pasca prosedur. Pada satu pasie lainya, pembuluh target harus diganti karena memberi perfusi pada daerah ventrikel kanan yang luas.

Kesimpulan PTSMA dengan panduan kontras ekokardiografi miokardium mampu laksana, efektif dan aman untuk menurunkan gradient tekanan JKVKi pada subyek KMH. (Med J Indones 2010; 19:164-71)

\begin{abstract}
Aim Percutaneous transluminal septal myocardial ablation (PTSMA), a non-surgical intervention to treat hypertrophic cardiomyopathy $(\mathrm{HCM})$, has been a standard treatment in developed countries. However, this procedure not yet systematically performed in Indonesia. This case series aim to study feasibility, safety and efficacy of PTSMA in National Cardiovascular Center Harapan Kita, Jakarta.

Methods Three HCM patients (2 male) with dynamic left ventricle outflow tract (LVOT) pressure gradient of higher than $30 \mathrm{mmHg}$ underwent PTSMA. Left ventricle apex pressure was measured using multipurpose catheter and aortic pressure was measured by means of left coronary guiding catheter simultaneously. Target vessel is confirmed by myocardial echocardiography contrast. Two $\mathrm{ml}$ absolute alcohol delivered to the target vessel by means over the wire balloon. Immediate pressure gradient changed 10 minute after alcohol administration was recorded. Continuous ECG monitoring is attemted along the procedure.

Results All subject demonstrated more than 50\% LVOT pressure gradient reduction. One subject experienced transient total AV block and right bundle branch block which completely recovered 6 hours after procedure. In one patient, target vessel must be changed as it gives perfusion to extensive area of right ventricle.

Conclusion PTSMA guided with myocardial echocardiography contrast is feasible, safe and effective to reduce LVOT pressure gradient in HCM patient. (Med J Indones 2009; 19:164-71)
\end{abstract}

Key words: percutaneous transluminal septal ablation, Indonesia

Percutaneous transluminal septal myocardial ablation (PTSMA), ${ }^{1}$ a non-surgical intervention modality has been widely proven as an effective treatment of hypertrophic cardiomyopathy (HCM). Symptomatic patients treated with PTSMA demonstrated better quality of live, reduces symptoms and decrease left ventricle outflow tract gradient (LVOT). Clinical benefits of PTSMA persist during short and long term follow-up., ${ }^{2,3}$

Correspondence email to: yogayun@yahoo.com
According to previous study, incidence of $\mathrm{HCM}$ is 1 among 500 populations. ${ }^{4} \mathrm{HCM}$ is an important disease as it might cause sudden death. Despite no epidemiology data of HCM in Indonesia but it is not infrequently found in clinical practice. In Indonesia, most of patients seek for medical help in late stage when the gradient of LVOT already very high with evidence of atrial fibrillation. Currently, HCM patients are treated pharmacologically with beta adrenergic blocker or non-dihydropiridine 
calcium channel blocker only. Treatment results were not sophisticated as the patients remain symptomatic and functionally limited. Hence, the needs for PTSMA in those patients are as of importance. We report our first three experiences in PTSMA of HCM patients.

\section{METHODS}

\section{Subjects}

This is a case series study enrolling three consecutive patients with symptomatic HCM. Symptoms considered resulted from HCM are as followed: dyspnea, chest pain, syncope or near syncope and palpitation. Definite diagnosis of HCM was made according to echocardiography finding.

Inclusion criteria are defined by echocardiography examinations as followed: hypertrophy of the left ventricle with septal wall thickness of more than $15 \mathrm{~mm}$, resting left ventricle outflow tract (LVOT) gradient of 30 $\mathrm{mmHg}$ or higher, and presence of systolic anterior motion (SAM) of anterior mitral leaflet (Figure 1). Written informed consent was obtained from all patients.

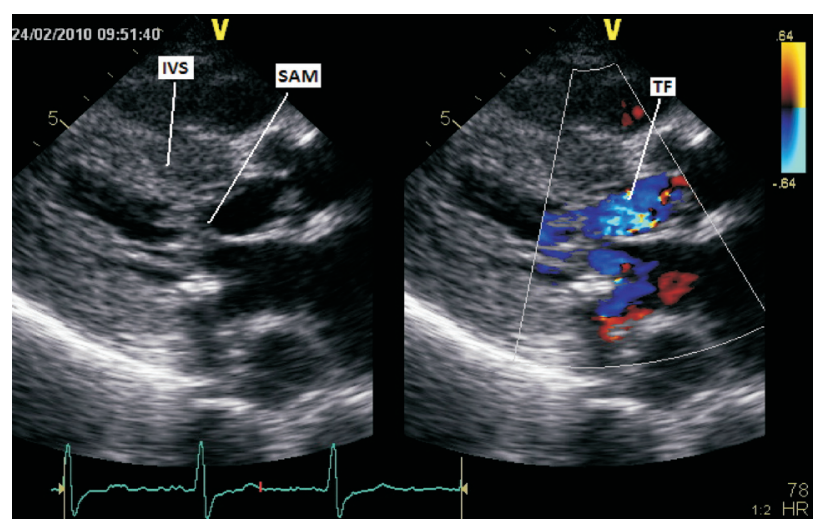

Figure 1. Long axis view of echocardiography demonstrates IVS hypertrophy and systolic anterior motion (SAM). IVS = interventricular septum, $T F=$ turbulence flow resulted from $S A M$

\section{Echocardiography}

All patients underwent echocardiography examination in catheterization laboratory prior to the procedure for baseline data and after myocardial contrast echocardiography (MCE) injection (Levovist ${ }^{\mathrm{TM}}$ ). Echocardiography examination was performed by cardiologist majoring in echocardiography which performed standard echocardiographic views (long axis, short axis, four chamber and subxyphoid) to evaluate septum wall thickness, systolic anterior motion (SAM), and LVOT pressure gradient. After injection of Levovist ${ }^{\mathrm{TM}}$ into septal artery, echocardiography examination intended to evaluate whether area out of obstructive septum involved or not. Peak instantaneous LVOT gradient was estimated with continuous wave Doppler.

\section{PTSMA}

PTSMA technique has been written elsewhere. ${ }^{1,2}$ In brief, after local anesthesia of both groin three vascular sheaths were inserted into femoral artery (6 French in left and 7 French in right) and left femoral vein (6 French). A $6 \mathrm{~F}$ bipolar temporary pacing electrode (Cordis $^{\mathrm{TM}}$, Johnson \& Johnson) was inserted through left femoral vein and placed at right ventricle apex. Coronary angiogram was performed to ensure normal coronary flow and anatomy. A multipurpose (MP) catheter (Cordis ${ }^{\mathrm{TM}}$, Johnson \& Johnson) was inserted into left ventricle through right femoral artery in order to continuously measure left ventricle cavity pressure. Recanulation of left coronary artery by means of extra backup (XB) guiding catheter (Cordis ${ }^{\mathrm{TM}}$, Johnson \& Johnson) followed by wiring of septal perforator branch of left anterior descending (LAD) artery using BMW guiding wire (Boston Scientific ${ }^{\text {TM }}$, USA) after 100 units per kilogram body weight unfractionated heparin injection. Over the wire (OTW) balloon was placed at proximal septal perforator branch and inflated up to 6 atmospheres. Selective contrast media injection was done to visualized septal artery vasculature in order to avoid spill off alcohol injection to LAD unintentionally. Three milliliter (ml) of Levovist ${ }^{\mathrm{TM}}$ injected into target artery followed by echocardiography confirmation. Intravenous injection of 2-3 milligram of morphine sulfate was given followed by slow injection of 2 $\mathrm{ml}$ absolute alcohol into target artery. OTW balloon remain inflated for ten minutes before pull it off. Repeat measure pressure gradient between left ventricle cavity and aorta. 


\section{RESULTS}

\section{Patient Characteristics}

Clinical characteristics of patients are as follow:

Tabel 1. Clinical characteristics

\begin{tabular}{|c|c|c|c|}
\hline Characteristics & Patient \# 1 & Patient \# 2 & Patient \# 3 \\
\hline Age & 73 & 37 & 30 \\
\hline Sex & $\mathrm{F}$ & M & M \\
\hline Symptom & Dyspnea & $\begin{array}{c}\text { Dyspnea } \\
\text { Presyncope }\end{array}$ & Dyspnea \\
\hline NYHA class & III & II & II \\
\hline $\mathrm{ECG}$ & $\begin{array}{l}\mathrm{SR}, \mathrm{RBBB}, \\
\mathrm{APC}\end{array}$ & $\mathrm{AF}$ & SR \\
\hline \multicolumn{4}{|l|}{ Echocardiography } \\
\hline $\begin{array}{l}\text { 1. Interventricular septal } \\
\text { thickness }\end{array}$ & $\begin{array}{l}19 \\
65\end{array}$ & $30-73$ & $\begin{array}{l}20 \\
86\end{array}$ \\
\hline 2. Dynamic LVOT gradient & $(+)$ & $(+)$ & $(+)$ \\
\hline 3. SAM & 13 & 24 & 13 \\
\hline $\begin{array}{l}\text { 4. Posterior wall thickness } \\
\text { 5. EF }\end{array}$ & 66 & 81 & 83 \\
\hline Coronary angiogram & Normal & Normal & Normal \\
\hline Medications & Metoprolol & Bisoprolol & Propanolol \\
\hline
\end{tabular}

NYHA $=$ New York Heart Association functional classification, $E C G=$ electrocardiography, $\mathrm{SR}=$ sinus rhythm, $\mathrm{RBBB}=$ right bundle branch block, $\mathrm{APC}=$ atrial premature contraction, $\mathrm{AF}=$ atrial fibrillation, $\mathrm{LVOT}=$ left ventricle outflow tract, $\mathrm{SAM}=$ systolic anterior motion, $\mathrm{EF}=$ ejection fraction.
The invasive resting maximal LVOT pressure gradients were 95,105 , and 40 in patients \# 1, 2 and 3 respectively. Post-extrasystolic maximal LVOT pressure gradient were 180,140 , and 82 in patients \# 1, 2 and 3 respectively. Immediately after PTSMA pressure gradient decrease by more than $50 \%$ in all three patients (Table 2 and Figure 2).

Tabel 2. Pressure gradient changes after PTSMA.

\begin{tabular}{lllllll}
\hline \multirow{2}{*}{ LVOT Pressure Gradient } & \multicolumn{2}{l}{ Patient \#1 } & \multicolumn{2}{c}{ Patient \#2 } & \multicolumn{2}{c}{ Patient\#3 } \\
\cline { 2 - 7 } & Pre & Post & Pre & Post & Pre & Post \\
\hline Resting (mmHg) & 95 & 25 & 105 & 14 & 40 & 7 \\
Post-extrasystolic (mmHg) & 180 & 40 & 140 & 35 & 82 & 36 \\
\hline
\end{tabular}

The target vessel was blocked completely in all patients (Figure 3). Levovist ${ }^{\mathrm{TM}}$ injection into septal perforator artery of patient \#1 demonstrated wide range of perfuse area to right ventricle papillary muscle and apex (Figure 4) leading to target vessel changed. Small septal artery proximal to septal perforator artery was then chosen and Levovist ${ }^{\mathrm{TM}}$ injection confirmed its perfusion into targeted septum (Figure 4). No significant and persistent complication in all patients. Patient \#3 experienced transient right bundle branch block (RBBB) and 3 beats of total AV block (TAVB).
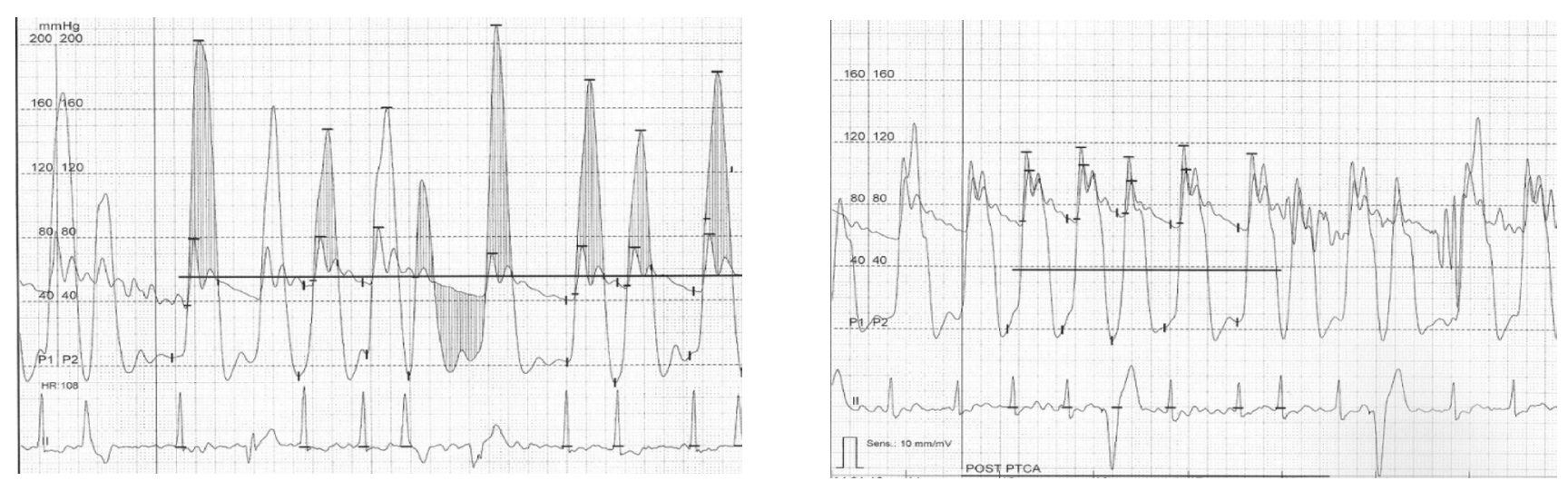

Figure 2. Invasive pressure recording of patients \#2 during sinus beat and post extrasystolic. Left panel showed LVOT pressure gradient before PTSMA which were reduce significantly after PTSMA (right panel). 

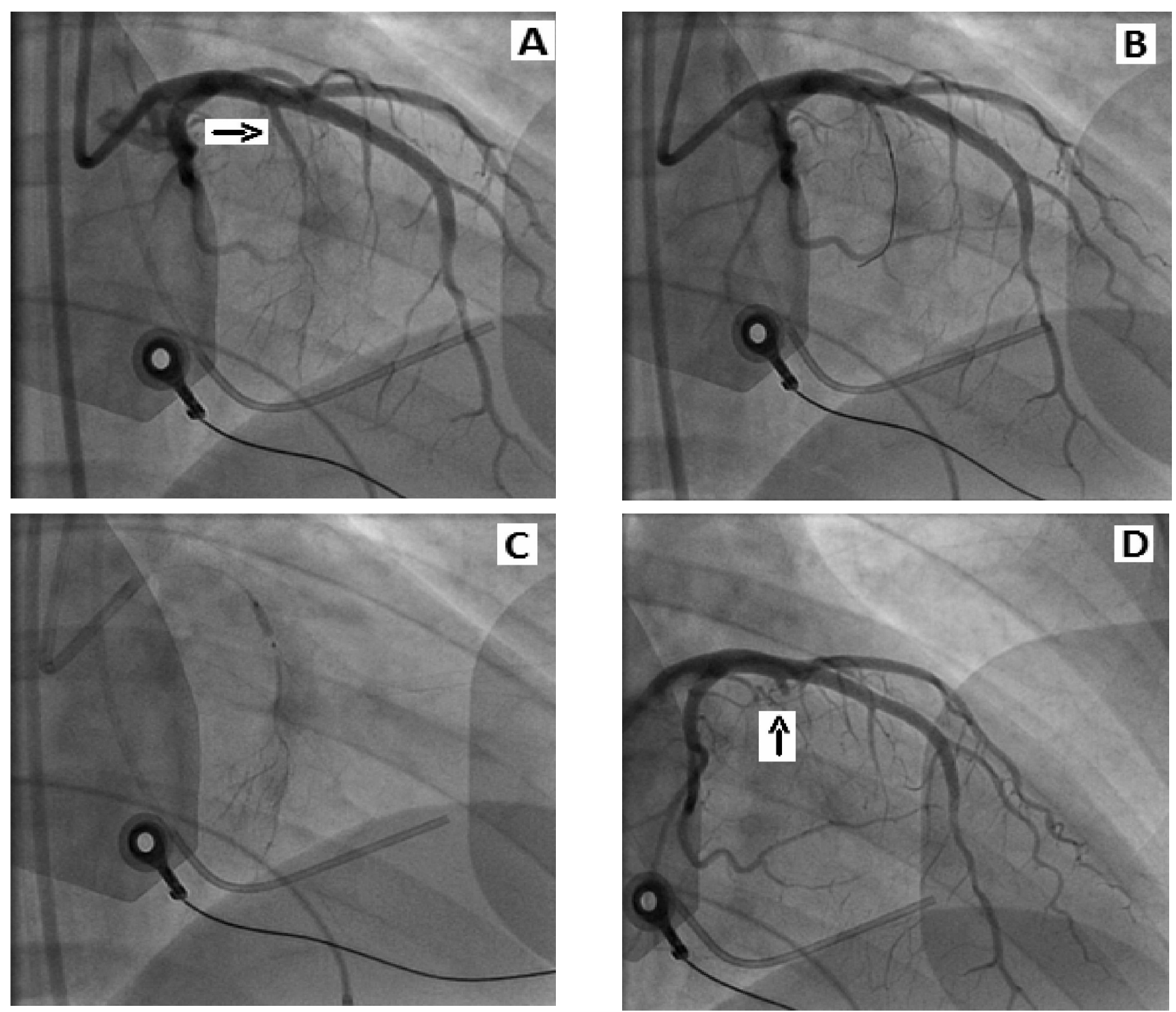

Figure 3. (A) Angiography of left coronary artery demonstrates septal perforator artery (arrow). (B) Septal perforator artery was blocked by over the wire (OTW) balloon. (C) BMW guide wire was retrieved followed by contrast media injection into the OTW balloon lumen shows ramification of septal branch which is not leakage into left anterior ascending artery. It is followed by 2 ml absolute alcohol injection. (D) LCA-graphy shows blockage of septal perforator artery 10 minutes after alcohol injection. 

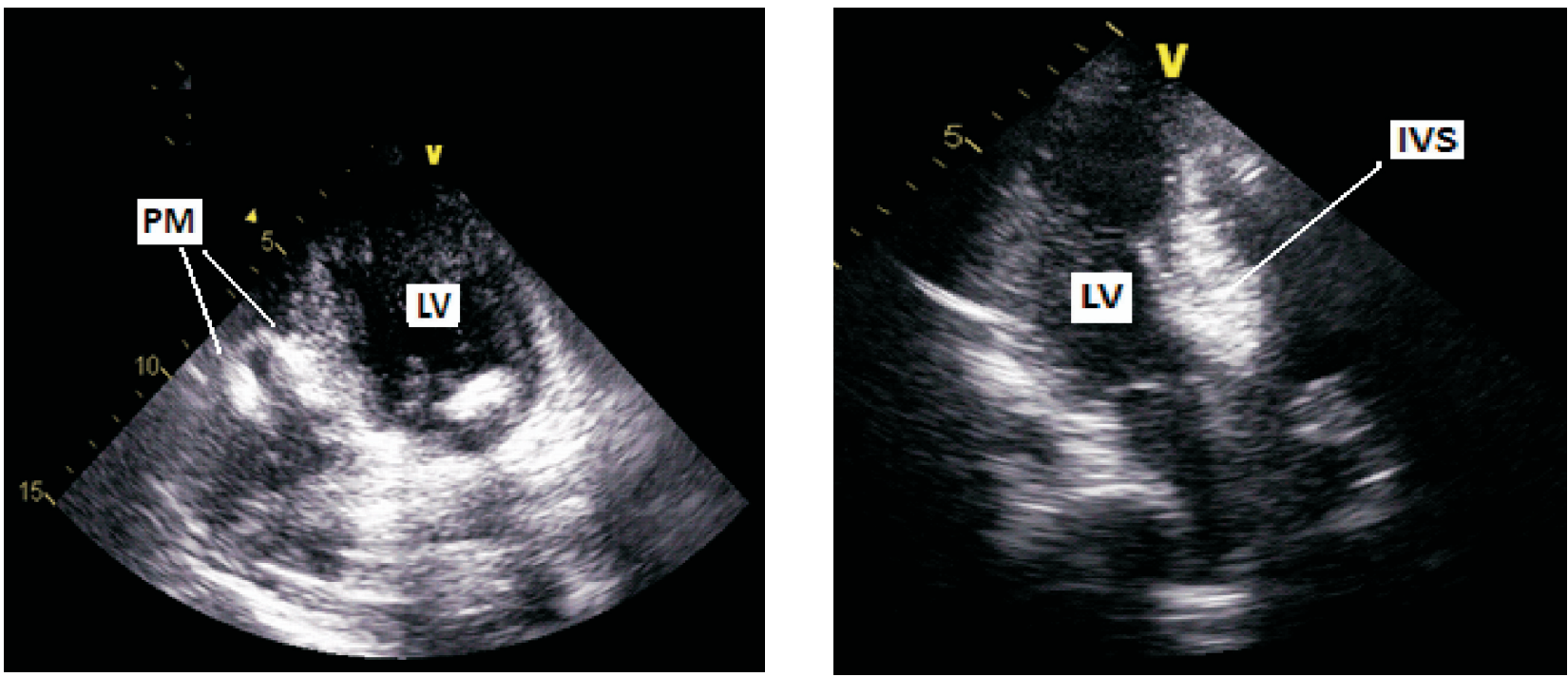

Figure 4. Myocardial contrast echocardiography by Levovist ${ }^{\mathrm{TM}}$ injection into septal perforator artery. Left panel was taken from patient \# 1 demonstrates myocardial contrast perfuse extensively to pappillary muscle (PM) of right ventricle leading to target vessel change. Right panel showed myocardial contrast filling limited to subaortic intraventricular septum which is confirmed the appropriate vessel target.

\section{DISCUSSION}

This study demonstrates initial results of effectiveness and safety of PTSMA in HCM patients in Indonesia. Left ventricle outflow tract pressure gradient immediately reduced after alcohol septal ablation without significant side effect.

Hypertrophic cardiomyopathy is unique among cardiovascular diseases by virtue of its potential for clinical presentation during any phase of life (from infancy to $>90$ years of age). As found in this case series the patients age invariably from 30 to 73 years old. Elderly HCM patients have been reported to compose as much as $25 \%$ of an HCM cohort, with only a minority having severe manifestations of heart failure. ${ }^{5}$ Outflow obstruction is commonly evident in about $40 \%$ patients of advanced age, suggesting that subaortic gradients may be well tolerated for long periods without adverse consequences. Indeed, HCM in elderly patients can be a genetic disorder caused by dominant sarcomere protein mutations most commonly in cardiac myosinbinding protein $\mathrm{C}$ and troponin I genes. ${ }^{6}$

Dyspnea is chief complain of all patients in this study and one patient suffered from near syncope as well. Maron et $\mathrm{al}^{5}$ studied $277 \mathrm{HCM}$ patients and found that $69 \%$ of them had no or mild symptoms, whereas $25 \%$ experienced severe symptoms or progressed to HCM- related death. During 8.1 \pm 6.6 years follow up they found that the most common symptoms were exertional dyspnea with or without fatigue followed by chest pain or both. New York Heart Association functional classification of our patients are class II to III which is similar to symptomatic patients group in previous study. ${ }^{5}$ They also found that NYHA functional class predicts survival whereas the higher the NYHA class (III and IV) the worse the survival. ${ }^{5}$ Exercise test should be performed to our patients before and after PTSMA to objectively measure the magnitude of functional capacity changes resulted from PTSMA.

Only patient \#3 demonstrates normal ECG pattern, the other two had arrhythmias at baseline. The 12-lead ECG pattern is abnormal in $75 \%$ to $95 \%$ of HCM patients and typically demonstrates a wide variety of patterns. ${ }^{5,7}$ Normal ECGs are most commonly encountered in family members identified as part of pedigree screening or when associated with mild localized LVH., ${ }^{5,7}$ Only a modest relation between ECG voltages and the magnitude of LVH assessed by echocardiography is evident. Nevertheless, ECGs have diagnostic value in raising a suspicion of $\mathrm{HCM}$ in family members without LVH on echocardiogram and in targeting athletes for diagnostic echocardiography as part of pre-participation screening. ${ }^{8}$

Clinical diagnosis of HCM is established most easily and reliably with 2-dimensional echocardiography 
by imaging the hypertrophied but non-dilated LV chamber, in the absence of another cardiac or systemic disease (eg, hypertension or aortic stenosis) capable of producing the magnitude of hypertrophy evident. ${ }^{9}$ Echocardiography examination in our cases consistently demonstrate interventricular septal thickness of more than $15 \mathrm{~mm}$ and presence of systolic anterior motion (SAM). Symptomatic patients showed increased LV wall thickness that range widely from mild (13-15 mm) to massive $(\geq 30 \mathrm{~mm}),{ }^{10,11}$ In trained athletes, modest segmental wall thickening (i.e. $13-15 \mathrm{~mm}$ ) raises the differential diagnosis between extreme physiologic LVH (i.e. athlete's heart) and mild morphologic expressions of $\mathrm{HCM},{ }^{12}$ which can usually be resolved with noninvasive testing. ${ }^{13}$ Magnetic resonance imaging may be of diagnostic value when echocardiographic studies are technically inadequate or in identifying segmental LVH undetectable by echocardiography.

SAM was seen in all three patients of our study. SAM resulted from suction effect of the LVOT ejection (Venturi effect). SAM causes further narrowing of the LVOT, in addition to the obstruction caused by the hypertrophied septum jutting into the LVOT. Abnormal orientation of the papillary muscle and the consequent pull can also contribute to the SAM. SAM septal contact time is the time during which the SAM touches the IVS. The more the SAM septal contact time, the more severe the LVOT obstruction. SAM septal contact also causes the formation of a plaque in this region, which could be a nidus for infective endocarditis in HCM. Another site for vegetations in HCM is the aortic valve on which the LVOT jet strikes, usually the ventricular aspect. Color flow mapping (CFM) during the SAM shows turbulent flow in the LVOT. A small mitral regurgitation jet might also visible behind the mitral valve, into the left atrium.

We use Levovist ${ }^{\mathrm{TM}}$ to visualize area of myocardium perfuse by corresponding septal artery. The use of myocardial contrast echocardiography (MCE) has been reported to increase LVOT pressure gradient reduction and decrease unnecessary complication. ${ }^{14}$ Case \#1 showed that septal perforator artery perfuse the right ventricle papillary muscle and apex beside part of the septal area hence the target vessel was changed to small septal branch proximal to septal perforator artery. Faber et al reported $7 \%$ of 131 patients whom were targeted by intraprocedural MCE showed the area distant from the expected septal target region was detected, leading to a target vessel change. ${ }^{15}$ Those finding leading to conclusion of importance to performed MCE routinely during PTSMA. Levovist ${ }^{\mathrm{TM}}$ has been an MCE agent of choice as it gives better echocardiographic image and does not cause allergic reaction.

Acute reduction of LVOT pressure gradient after PTSMA was more than $50 \%$ in all three patients either at rest or post-extrasystol. LVOT pressure gradient reduction of $50 \%$ has been an end point during PTSMA, ${ }^{16}$ however many studies demonstrated reduction of more than that. ${ }^{2,} 3$ Resting LVOT pressure gradient was more than $30 \mathrm{mmHg}$ in all three patient of this study. Gietzen et al. ${ }^{17}$ compared the results of PTSMA in 45 consecutive patients with LVOT pressure gradients of $<$ $30 \mathrm{~mm} \mathrm{Hg}$ at rest and $>30 \mathrm{~mm} \mathrm{Hg}$ after provocation to outcomes of 84 patients with outflow obstruction under basal conditions. PTSMA had beneficial clinical and hemodynamic effects in patients with either provocable or resting outflow obstruction.

The amount of absolute alcohol injected into target vessel had been an area of studied recently. Our protocol use $2 \mathrm{ml}$ absolute alcohol injection which is proven effective to blocked septal artery in our cases. With focus on the median value of the alcohol quantity, Kuhn et a ${ }^{18}$ patients treated with high amounts $(>2 \mathrm{ml})$ showed a higher total mortality than patients treated with small amounts $(<2 \mathrm{ml})$ and alcohol turned out to be an independent predictor of survival.

Patient \#3 experienced transient TAVB and RBBB which was completely resolved in the same day. In case series of 9 patients, Kazmierczak et al ${ }^{19}$ reported all patients developed RBBB immediately after PTSMA and 5 of them were resolved during 6 months follow up. Transient and persistent TAVB that need permanent pacemaker implantation has been studied recently. Preexisting left bundle branch block is a predictor of persistent TAVB after PTSMA. ${ }^{20}$ Delayed TAVB might also happen which is then ECG monitoring better extended up to 4 days after PTSMA. ${ }^{21}$ Alcohol septal ablation for HCM induces significant changes in the resting ECG in most patients, despite the occlusion of a relatively small artery. The changes include new Q waves, new bundle branch block, transient anterior ST segment elevation, atrioventricular block, and transient prolongation of QT interval. ${ }^{19}$

PTSMA is an alternative to surgical myectomy which is the gold standard to relieve LVOT obstruction in HCM. However, unlike coronary artery disease patients HCM patients and their doctors are not so eager to proceed to surgical treatment. Septal myectomy is rarely 
performed in our institution due to lack of operator interest. Compare to surgical myectomy, PTSMA as a non-surgical intervention is more convenient to patient with less hospital length of stay. A non-randomized study ${ }^{16}$ comparing PTSMA and surgical myectomy revealed that both modalities give similar survival rate during 4 years follow up. Kaplan Meier analysis showed that survival free of death and severe symptoms overall of PTSMA patients was similar to that of myectomy patients. However in that study, survival free of death and severe symptoms was lower among patients $\leq 65$ years of age who underwent ablation than among patients of the same age who underwent myectomy. ${ }^{16}$ They reported that myectomy had fewer procedural complications. ${ }^{16}$ Meanwhile more recent study by Firoozi et al. ${ }^{22}$ who conducted a nonrandomized cohort study comparing surgical myectomy to alcohol ablation in 44 patients with symptomatic, drug-refractory obstructive HCM. Twenty-four patients underwent surgical myectomy, and 20 patients underwent PTSMA. The authors concluded that surgical myectomy and alcohol septal ablation are equally effective at reducing obstruction and subjective exercise limitation in appropriately selected patients. Sitges et al. ${ }^{23}$ compared outcomes of left ventricular diastolic function in a cohort of 57 patients. PTSMA was performed in 37 patients, and 20 patients underwent surgical myectomy. When comparing PTSMA to myectomy, the results revealed no difference in the degree of change in any parameter of diastolic function. Another study by Gietzen et al. demonstrated no difference of PTSMA efficacy between patient aged under and older than 60 years old. ${ }^{24}$ Zeng et al. ${ }^{25}$ in their meta-analysis of three studies compared PTSMA to septal myectomy. The metaanalysis accorded with all three trials, which showed that both PTSMA and septal myectomy could decrease IVS thickness with similar results and that PTSMA and septal myectomy improved the NYHA class and had similar results. The meta-analysis of the PTSMA and septal myectomy on LVOT gradient demonstrated that two reports found the same effect, while the third found the septal myectomy to be more effective than the PTSMA. The meta-analysis concurred with the latter report and agreed that the effect of the septal myectomy was better. In conclusion, the authors suggested the need for large, randomized controlled trials comparing these two treatments, including exercise test parameters and long- term prognosis.

In conclusion, our initial results of PTSMA demonstrated immediate LVOT pressure gradient reduction without significant complication. PTSMA will be a new therapeutic modality to treat HCM in our institution.

\section{REFERENCES}

1. Seggewiss H. Percutaneous transluminal septal myocardial ablation: a new treatment for hypertrophic obstructive cardiomyopathy. Eur Heart J. 2000;21704-7.

2. Seggewiss H, Gleichmann U, Faber L, Fassbender D, Schmidt HK, Strick S. Percutaneous transluminal septal myocardial ablation in hypertrophic obstructive cardiomyopathy: acute results and 3-month follow-up in 25 patients. J Am Coll Cardiol. 1998;31:252-8.

3. Faber L, Meissner A, Ziemssen P, Seggewiss H. Percutaneous transluminal septal myocardial ablation for hypertrophic obstructive cardiomyopathy: long term follow up of the first series of 25 patients. Heart. 2000;83:326-31.

4. Maron BJ, Gardin JM, Flack JM, Gidding SS, Kurosaki TT, Bild DE. Prevalence of hypertrophic cardiomyopathy in a general population of young adults. Echocardiographic analysis of 4111 subjects in the CARDIA Study. Coronary Artery Risk Development in (Young) Adults. Circulation. 1995;92:785-9.

5. Maron BJ, Casey SA, Poliac LC, Gohman TE, Almquist AK, Aeppli DM. Clinical course of hypertrophic cardiomyopathy in a regional United States cohort. JAMA. 1999;281:650-5.

6. Niimura H, Patton KK, McKenna WJ, Soults J, Maron BJ, Seidman JG, Seidman CE. Sarcomere protein gene mutations in hypertrophic cardiomyopathy of the elderly. Circulation. 2002;105:446-51.

7. Maron BJ. The electrocardiogram as a diagnostic tool for hypertrophic cardiomyopathy: revisited. Ann Noninvasive Electrocardiol. 2001;6:277-9.

8. Maron BJ. Hypertrophic cardiomyopathy: a systematic review. JAMA. 2002;287:1308-20.

9. Klues HG, Schiffers A, Maron BJ. Phenotypic spectrum and patterns of left ventricular hypertrophy in hypertrophic cardiomyopathy: morphologic observations and significance as assessed by two-dimensional echocardiography in 600 patients. J Am Coll Cardiol. 1995;26:1699-708.

10. Spirito P, Bellone P, Harris KM, Bernabo P, Bruzzi P, Maron BJ. Magnitude of left ventricular hypertrophy and risk of sudden death in hypertrophic cardiomyopathy. N Engl J Med. 2000;342:1778-85.

11. Elliott PM, Gimeno Blanes JR, Mahon NG, Poloniecki JD, McKenna WJ. Relation between severity of left-ventricular hypertrophy and prognosis in patients with hypertrophic cardiomyopathy. Lancet. 2001;357:420-4.

12. Pelliccia A, Maron BJ, Spataro A, Proschan MA, Spirito P. The upper limit of physiologic cardiac hypertrophy in highly trained elite athletes. N Engl J Med. 1991;324:295-301.

13. Maron BJ, Pelliccia A, Spirito P. Cardiac disease in young trained athletes. Insights into methods for distinguishing athlete's heart from structural heart disease, with particular emphasis on hypertrophic cardiomyopathy. Circulation. 1995;91:1596-601. 
14. Faber L, Seggewiss H, Gleichmann U. Percutaneous transluminal septal myocardial ablation in hypertrophic obstructive cardiomyopathy: results with respect to intraprocedural myocardial contrast echocardiography. Circulation. 1998;98:2415-21.

15. Faber L, Ziemssen P, Seggewiss H. Targeting percutaneous transluminal septal ablation for hypertrophic obstructive cardiomyopathy by intraprocedural echocardiographic monitoring. J Am Soc Echocardiogr. 2000;13:1074-9.

16. Sorajja P, Valeti U, Nishimura RA, Ommen SR, Rihal CS, Gersh BJ, Hodge DO, Schaff HV, Holmes DR, Jr. Outcome of alcohol septal ablation for obstructive hypertrophic cardiomyopathy. Circulation. 2008;118:131-9.

17. Gietzen FH, Leuner CJ, Obergassel L, Strunk-Mueller C, Kuhn H. Role of transcoronary ablation of septal hypertrophy in patients with hypertrophic cardiomyopathy, New York Heart Association functional class III or IV, and outflow obstruction only under provocable conditions. Circulation. 2002;106:454-9.

18. Kuhn H, Lawrenz T, Lieder F, Leuner C, Strunk-Mueller C, Obergassel L, Bartelsmeier M, Stellbrink C. Survival after transcoronary ablation of septal hypertrophy in hypertrophic obstructive cardiomyopathy (TASH): a 10 year experience. Clin Res Cardiol. 2008;97:234-43.

19. Kazmierczak J, Kornacewicz-Jach Z, Kisly M, Gil R, Wojtarowicz A. Electrocardiographic changes after alcohol septal ablation in hypertrophic obstructive cardiomyopathy. Heart. 1998;80:257-62.

20. El-Jack SS, Nasif M, Blake JW, Dixon SR, Grines CL, O'Neill WW. Predictors of complete heart block after alcohol septal ablation for hypertrophic cardiomyopathy and the timing of pacemaker implantation. J Interv Cardiol. 2007;20:73-6.

21. Kern MJ, Holmes DG, Simpson C, Bitar SR, Rajjoub H. Delayed occurrence of complete heart block without warning after alcohol septal ablation for hypertrophic obstructive cardiomyopathy. Catheter Cardiovasc Interv. 2002;56:503-7.

22. Firoozi S, Elliott PM, Sharma S, Murday A, Brecker SJ, Hamid MS, Sachdev B, Thaman R, McKenna WJ. Septal myotomy-myectomy and transcoronary septal alcohol ablation in hypertrophic obstructive cardiomyopathy. A comparison of clinical, haemodynamic and exercise outcomes. Eur Heart J. 2002;23:1617-24.

23. Sitges M, Shiota T, Lever HM, Qin JX, Bauer F, Drinko JK, Agler DA, Martin MG, Greenberg NL, Smedira NG, Lytle BW, Tuzcu EM, Garcia MJ, Thomas JD. Comparison of left ventricular diastolic function in obstructive hypertrophic cardiomyopathy in patients undergoing percutaneous septal alcohol ablation versus surgical myotomy/myectomy. Am J Cardiol. 2003;91:817-21.

24. Gietzen FH, Leuner CJ, Obergassel L, Strunk-Mueller C, Kuhn H. Transcoronary ablation of septal hypertrophy for hypertrophic obstructive cardiomyopathy: feasibility, clinical benefit, and short term results in elderly patients. Heart. 2004;90:638-44.

25. Zeng Z, Wang F, Dou X, Zhang S, Pu J. Comparison of percutaneous transluminal septal myocardial ablation versus septal myectomy for the treatment of patients with hypertrophic obstructive cardiomyopathy--a meta analysis. Int J Cardiol. 2006;112:80-4. 